\section{Swirski Mite Controlled-release Sachets as a Pest Management Tool in Container Tree Production}

\author{
Karla M. Addesso ${ }^{1,3}$, Anthony L. Witcher ${ }^{1}$, and Donna C. Fare ${ }^{2}$
}

AdDitional index words. Amblyseius swirskii, container, shade house, broad mite, spider mite, thrips

\begin{abstract}
SUMMARY. Adoption of biological control tools in woody ornamental nursery production has lagged behind other agriculture fields. One of the major obstacles to adoption is lack of information on the efficacy of various biological control agents in nursery production systems. The predatory mite Amblyseius swirskii, sold commercially as "swirski mite," is a generalist predatory mite that has recently been adopted as a generalist control for a wide range of mite and insect pests, including thrips (Thripidae), whiteflies (Aleyrodidae), eriophyid mites (Eriophyidae), broad mite (Polyphagotarsonemus latus), and spider mites (Tetranychidae). A controlledrelease sachet formulation of swirski mite was evaluated in three experiments to determine whether size of the tree, timing of first application, or sun intensity would affect treatment efficacy. Pest numbers on plants was evaluated biweekly for 12 weeks. The swirski mite sachets controlled broad mite and spider mite outbreaks on red maple trees (Acer rubrum) grown in nos. 3 and 15 nursery containers, respectively. Application at the time of red maple rooted cutting transplant was not necessary to achieve summer-long control of pests. No outbreaks of target pests on flowering dogwood (Cornus florida) in no. 5 containers grown under both full sun and shade, but with low levels of broad mite persisting in the shade treatment and thrips persisting in sun. These results suggest that swirski mite is a promising candidate for biological control in woody ornamental nursery production.
\end{abstract}

$\mathrm{W}$ oody ornamental nurseries in the southeastern United States are diverse agroecosystems, where plants from dozens of species and genera may be grown in adjacent blocks or container yards. The diversity within the nursery results in an array of potential pest problems, depending on the time of year or plant species in question. In vegetable and row crop systems, key pests have been well characterized and management plans are available for most regions in the National integrated pest management (IPM) Database, where fewer resources are available for nursery growers (Southern IPM Center, 2018). The sheer diversity of plant material makes

Funding was provided by USDA-NIFA Evans-Allen Program.

We thank Megan Patton and Paul O’Neal for their assistance with data collection.

${ }^{1}$ Department of Agricultural and Environmental Science, Otis L. Floyd Nursery Research Center, Tennessee State University, McMinnville, TN 37110

${ }^{2}$ Floral and Nursery Plants Research, Agricultural Research Service, United States Department of Agriculture, Otis L. Floyd Nursery Research Center, McMinnville, TN 37110

${ }^{3}$ Corresponding author. E-mail: kaddesso@tnstate. edu.

https://doi.org/10.21273/HORTTECH03934-17 ornamental production more difficult to manage, given that pest complexes on most plants have not been studied at all, and where they have, severity of damage may differ between related species and cultivars. However, several major pest groups that attack a wide range of woody host plants, including broad mite, spider mites, eriophyid mites, thrips, and whiteflies (Southern Nursery IPM Working Group, 2014). In field and container nursery production in the southeastern United States, these pests are generally managed through cultural practices and rotations of conventional pesticides (North Carolina State University, 2017).

In recent years, augmentative biological control has become the core component of IPM programs in greenhouse ornamental production and other vegetable and fruit cropping systems (Buitenhuis et al., 2015; Pilkington et al., 2010). Most of the applied biological control research in ornamentals as a whole has been conducted on greenhouse floriculture and targeted specific pests and crops such as whitefly in poinsettia [Euphorbia pulcherrima (van Driesche and Lyon, 2003)] or spider mites and thrips on roses [Rosa sp. (Casey et al., 2007)]. The same cannot be said of woody ornamental nursery production, where relatively little applied research has been conducted on the use of biological control agents for pest management. Most of the work conducted to date in nursery production has been performed by biological control companies consulting with private nursery owners to address specific pests.

A large-scale evaluation of persimilis mite (Phytoseiulus persimilis) for control of two-spotted spider mite (Tetranychus urticae) on croton (Codiaeum variegatum) and areca palm (Chrysalidocarpus lutescens) was conducted in a Florida production facility (Cashion et al., 1994). Release of predatory mites on croton reduced the number of miticide applications by $87 \%$ to $92 \%$ compared with those made to control plants. No miticides were required on the areca palms treated with predatory mites over the 8-month trial period, whereas the control block required miticide applications at 10- to 14 -d intervals. Subsequent releases were made every 2 weeks with one predator per plant. Pratt and Croft (2000) evaluated fallacis mite (Neoseiulus fallacis) and determined it was the best spider mite control agent in Pacific northwestern U.S. woody landscape plants such as freeman maple (Acer $\times$ freemanii), apple (Malussp.), spirea (Spirea bumalda), and rhododendron (Rhododendron sp.) because of its relatively wide host range and overwintering ability. Pratt et al.

\begin{tabular}{llll}
\hline $\begin{array}{l}\text { Units } \\
\begin{array}{l}\text { To convert U.S. to SI, } \\
\text { multiply by }\end{array}\end{array}$ & U.S. unit & SI unit & $\begin{array}{l}\text { To convert SI to U.S., } \\
\text { multiply by }\end{array}$ \\
\hline 29.5735 & $\mathrm{fl} \mathrm{oz}$ & $\mathrm{mL}$ & 0.0338 \\
0.3048 & $\mathrm{ft}$ & $\mathrm{m}$ & 3.2808 \\
3.7854 & $\mathrm{gal}$ & $\mathrm{L}$ & 0.2642 \\
2.54 & inch $(\mathrm{es})$ & $\mathrm{cm}$ & 0.3937 \\
0.5933 & $\mathrm{lb} / \mathrm{yard} \mathrm{d}^{3}$ & $\mathrm{~kg} \cdot \mathrm{m}^{-3}$ & 1.6856 \\
28.3495 & $\mathrm{oz}$ & $\mathrm{g}$ & 0.0353 \\
$\left({ }^{\circ} \mathrm{F}-32\right) \div 1.8$ & ${ }^{\circ} \mathrm{F}$ & ${ }^{\circ} \mathrm{C}$ & $\left({ }^{\circ} \mathrm{C} \times 1.8\right)+32$
\end{tabular}


(2002) also compared control of spider mites by fallacis mites on 30 cultivars of landscape plants with different growth habits and found that canopy density was a strong factor for success, with predators performing better on shrubs and herbaceous perennials and less on conifers and shade trees. The authors did not observe differences in spider mite control between containerized and field-grown plants.

One predatory mite of particular interest for use in woody ornamental nursery production is the swirski mite. Introduced in 2005 to the market, swirski mite is currently released by commercial growers in more than 50 countries and can feed, develop, or do both on prey in assorted families of mites (Eriophyidae, Tarsonemidae, Tenuipalpidae, and Tetranychidae) and insects (Aleyrodidae, Aphididae, Diaspididae, Phoenicoccidae, Pseudococcidae, Thripidae, Noctuidae, Pyralidae, and Psyllidae) (Calvo et al., 2015). Swirski mite is an effective predator of broad mite (Onzo et al., 2012; Peña and Osborne, 1996; Tal et al., 2007; van Maanen et al., 2010) and can reproduce on various species of thrips, whitefly, spider mite (Calvo et al., 2015), insect eggs (Delisle et al., 2015), and asian citrus psyllid [Diaphorina citri (Juan-Blasco et al., 2012)]. Populations of swirski mite can be maintained on various species of pollen if no other insect food sources are available (Goleva and Zebitz, 2013). This flexibility in diet allows populations of swirski mite to establish and survive long periods in the absence of suitable prey (Goleva and Zebitz, 2013; Xiao et al., 2012).

In addition to its diet flexibility, swirski mite performs better than other commercially available mite predators at higher temperatures in the 30 to $32{ }^{\circ} \mathrm{C}$ range (Lee and Gillespie, 2011) and under simulated summer greenhouse conditions with widely fluctuating temperature and humidity levels (Hewitt et al., 2015). It can establish on mock orange [Murraya paniculata (Juan-Blasco et al., 2012)] and citrus [Citrus sp. (Palevsky et al., 2003)], suggesting it may also be an effective option in other ornamental trees and shrubs. Because some trees, such as flowering dogwood, prefer shaded conditions but are often grown in full sun
(Burrows et al., 2015), there is a need for flexibility in a predator's tolerance to different growing conditions, which can change from year-to-year or within the same season. For these reasons, swirski mite appears to have good potential as a tool for woody ornamental production in the southeastern United States.

Priorities for pest management research listed by the Southern Nursery IPM Working Group (2014) include eriophyid mites, spider mites, broad mite, and thrips-all pests that swirski mite will readily attack. Of particular interest are new methods for managing broad mite, which can be difficult to control with miticide applications alone. Based on the needs of the southeastern U.S. nursery industry and the dearth of efficacy data on the use of this predatory mite in woody ornamental production, this research was undertaken.

The goal of this study was to evaluate swirski mite in woody ornamental container production using a controlled-release sachet method of deployment. The sachet deployment method is marketed as a way to reduce the number of application intervals by allowing continued introduction of predators from the breeding colony kept within the sachet. However, detail is lacking on the appropriate use of sachets in woody ornamentals with regard to efficacy on small and large canopy trees, timing of first application, efficacy in shade vs. sun, etc. Deployment recommendations are based on greenhouse crops such as pepper (Capsicum annuum). Such recommendations may or may not correlate directly with the canopy size of individual trees in ornamental production. Often, the canopies of greenhouse or row crops are continuous, creating one large interconnected patch within which predators can disperse in search of prey (Casey and Parrella 2005). Woody plants can be arranged in such a way that each tree canopy is its own separate patch, making it more likely that predators will deplete their food sources and more difficult for the predators to disperse across the crop. Current sachet application recommendations also suggest that deploying sachets a few weeks before pest pressure is known to peak, giving the predators time to build up their populations.
Given the complexity of nursery production, it might be more appropriate to time the application of sachets with normal nursery routines such as transplant of liners into containers or deployment of overwintered material into container yards. In that way, the addition of sachets to the containers can be incorporated into current labor activities. In addition to the aforementioned concerns, there are also questions about the variability of production methods for certain plants, particularly those that might be grown in shade and sun. As microclimate could potentially alter the efficacy of both the sachets (Shimoda et al., 2017) and predators (Hewitt et al., 2015; Lee and Gillespie, 2011), it is important to know if this particularly release method will provide similar results under both conditions.

To assess the potential for the use of swirski sachets in outdoor container production of trees, we identified three questions of interest related to production practices. These questions address canopy size effects, timing of incorporation of sachets into the current production cycle, and differences of microclimate in trees grown under shade or full sun. The three experiments were conducted to answer the following questions: 1) Do the mites from the controlled-release sachets perform differently on small trees and large trees? 2) What is the optimal number of applications in the production cycle following transplant of rooted cuttings? 3) Is there a difference in the performance of sachets under shade cover or full sun?

\section{Materials and methods}

Slow-release predator sachets are one of several methods available to growers who wish to add biological control programs to their management practices. The sachets contain a starter colony of predators, a carrier matrix, and a food source-commonly a species of grain mite (Tyrophagus putrescentiae). The concept behind the sachet is that predators will reproduce on the grain mite and slowly disperse out onto the crop as their food is depleted over the next few weeks (Hoogerbrugge et al., 2008). A subsample of sachets from each shipment was opened and evaluated for the presence of live and actively 
foraging predators prior on the day the shipment arrived. Mite sachets were deployed on the day of arrival. Plots were observed weekly and in cases where the sachet hangers failed or became dislodged, they were immediately reattached within the plant canopy. All experiments were conducted at the Tennessee State University Otis L. Floyd Nursery Research Center in McMinnville, TN.

EXPT. 1. Size OF PLANTS TREATED. The goal of this experiment was to determine if applying swirski mite controlled-release sachets [Swirskiline Controlled-Release System; Bioline AgroSciences, Little Clacton, UK (formerly Syngenta Bioline, Basel, Switzerland)] to newly transplanted rooted cuttings was as effective as applications made to larger containerized trees. Based on the voracious nature of swirski mite and the greater food source availability on larger trees, it will likely establish and maintain a population on the larger containerized plants. Swirski mite applied to the smaller patches of the newly transplanted liners are more likely to consume all available prey and cannibalize one another if no other food sources are available.

'Sun Valley' red maple trees were treated in 2016 at two different stages: rooted cuttings $(6-12$ inches tall, 4-inch pots) transplanted into no. 3 containers $[3$ gal (Classic 1200; Nursery Supplies, Chambersburg, PA)] and overwintered no. 15 trees $(\approx 2$-inch trunk diameter at 6 inches above potting substrate, 12$16 \mathrm{ft}$ tall) [13.4 gal (Classic 6900; Nursery Supplies)]. 'Sun Valley' red maple rooted cuttings were transplanted in Apr. 2016 into no. 3 containers with $100 \%$ pine bark substrate amended with $10.0 \mathrm{lb} /$ yard $^{3}$ $19 \mathrm{~N}-2.2 \mathrm{P}-7.5 \mathrm{~K}, 12$ - to 14 -month controlled-release fertilizer (Osmocote Pro 19-5-9; ICL Specialty Fertilizers, Dublin, OH), $1.5 \mathrm{lb} /$ yard $^{3}$ micronutrient fertilizer (Micromax; ICL Specialty Fertilizers), and $1 \mathrm{lb} /$ yard $^{3}$ of a wetting agent (AquaGro; Aquatrols, Paulsboro, NJ). The plants were placed on a gravel container pad with overhead irrigation and watered daily.

'Sun Valley' red maple trees in no. 15 containers were propagated in Summer 2011 as rooted cuttings (612 inches tall, 4 -inch pots), transplanted in Spring 2012 into no. 3 containers, and then repotted into no. 15 containers in Apr. 2013 with amended bark substrate described previously. All plants were kept in a pot-in-pot system until use in this study in Apr. 2016. The trees were fertilized annually (2014-16) with a top-dress application of $8.8 \mathrm{oz}$ of $19 \mathrm{~N}-2.2 \mathrm{P}-7.5 \mathrm{~K}$ controlled-release fertilizer and irrigated daily with microspray stake irrigation (Netafilm USA, Fresno, CA).

Ten trees in each size container were arranged in a randomized complete block design and treated with swirski mite sachets. One sachet containing a swirski mite colony was applied to each tree on 29 Apr. 2016 and again on 22 June 2016. Ten trees in each size container did not receive a sachet and acted as untreated controls. The plants were arranged in a way that treatments and control canopies did not touch (2 $\mathrm{m}$ spacing).

EXPT. 2. NUMB ER OF APPLICATIONS. The goal of this experiment was to identify optimal timing of swirski mite application in propagated cuttings. Two times were identified in the production cycle where labor is already handling the plants and sachet attachment might be added to the process: transplant of rooted cutting into no. 3 container or movement of overwintered transplants into the container yard. These two treatments also represent an early and late first application, which may affect predator establishment on the crop. To evaluate whether the number of applications is important, 'Franksred' Red Sunset ${ }^{\circledR}$ red maple trees were grown in no. 3 containers as described previously. One sachet was applied to each plant on 31 Mar., 29 Apr., and 22 June 2016 (hereafter referred to as "Three" application) or on 29 Apr. and 22 June 2016 (hereafter referred to as "Two" application). Ten tree replications were evaluated per treatment and an additional 10 "Untreated" trees were used as controls. The plants were arranged in a randomized complete block design and spaced in a way that treatment and control canopies did not touch.

Expt. 3. Full sun versus SHADE. The goal of this experiment was to evaluate pest population levels under shade ("Shade") and full sun ("Sun") conditions when treated with swirski mite. In Apr. 2016, 'Cherokee Princess' bare-root flowering dogwood liners ranging from 18 to 24 inches in height were obtained from a commercial nursery in Winchester, TN. Liners (2-3 ft tall) were potted into no. 5 nursery containers [3.7 gal (Classic 1600; Nursery Supplies) with $100 \%$ pine bark substrate amended with $5.6 \mathrm{lb} /$ yard $^{3} 19 \mathrm{~N}-$ 2.2P-7.5K controlled-release fertilizer, $1.2 \mathrm{lb} /$ yard $^{3}$ micronutrient fertilizer, and $1 \mathrm{lb} /$ yard $^{3}$ of wetting agent. The plants were moved onto a gravel pad in full sun or under $50 \%$ white shadecloth (Dewitt, Sikeston, MO) with 10 plants per treatment. Cyclic irrigation was applied twice daily in early spring and increased to three applications daily during periods of increased heat throughout the summer. Water was applied using a $160^{\circ}$ fan emitter (Spot-Spitter; Roberts Irrigation Co., San Marcos, CA). Trees were assigned to Sun and Shade treatments in a completely randomized design and one sachet was placed on each plant on 29 Apr. and 22 June 2016.

SAmpling. For all three experiments, tree height was measured before experiment initiation and at the end of the season. Leaf samples in all experiments were taken every 2 weeks from 15 June 2016 to 25 Aug. 2016 for a total of six sampling dates. The trees were sampled by removing two newly emerging leaves from each tree replication and placing them into a $15-\mathrm{mL}$ centrifuge tube (Falcon Tube; Corning, Corning, NY) with $70 \%$ ethanol (Fisher Bioreagents; Fisher Scientific, Hampton, NH) for transport and storage until samples could be evaluated. Leaves were taken from two different branches per plant on opposite sides of the canopy. The samples were evaluated by vortexing the sample vials to knock off insects and mites and ethanol was poured through a Whatman filter paper funnel (GE Healthcare, Little Chalfont, UK). Broad mite, spider mites, thrips, and predatory mites (all Phytoseiidae, including recovered swirskii) were counted on the funnel paper and broad mite eggs were counted on the leaf surface. Other insects and eggs were counted, pooled, and reported as "Other Insects."

Data analysis. Height measurements were compared using full factorial design (Expt. 1) and one-way 
design (Expts. 2 and 3) [PROC GENMOD (SAS version 9.3; SAS Institute, Cary, NC)] under a normal distribution. Count data for arthropods were pooled across sample dates by replication because of low counts at individual sampling periods and analyzed by full factorial design (Expt. 1) and one-way design (Expts. 2 and 3 ) with a generalized linear model with means transformed with a log link function and fit to a negative binomial distribution (PROC GENMOD, SAS version 9.3). Means for all analyses were separated using Fisher's protected least significant difference at $P \leq 0.05$ for multiple comparisons.

\section{Results}

EXPt. 1. Size OF PLANTS TREATED. Trees in no. 3 containers grew more over the evaluation period than trees in no. 15 containers, but there was no effect of swirski mite application on tree height $[($ mean \pm $\mathrm{SE})$ no. 3 untreated $=87.4 \pm 6.7 \mathrm{~cm}$, no. 3 -swirski mite $=86.3 \pm 4.5 \mathrm{~cm}$, no. 15 untreated $=44.8 \pm 9.5 \mathrm{~cm}$, no. 15 -swirski mite $=71.5 \pm 13.5 \mathrm{~cm}$; Treatment $\chi_{(\mathrm{df})}: \chi^{2}{ }_{(1)}=2.11, P=$ 0.15 , Size: $\chi_{(1)}^{2}=9.63, P=0.00$; and Treatment $\times$ Size: $\chi_{(1)}^{2}=2.48, P=$ $0.12]$. More prey were observed on nos. 3 and 15 untreated trees than on trees treated with swirski mite (Table 1). In no. 3 containers, more broad mites were observed in untreated plants than swirski mite-treated plants. On no. 15 containers, more spider mites and unidentified eggs and insects were observed on untreated plants. However, more broad mite eggs were observed on swirski mite-treated plants than untreated controls. Peak broad mite activity occurred on no. 3 plants in midAugust, whereas spider mite populations on no. 15 plants peaked 1 month earlier in July (Fig. IA and C). Predatory mites were recovered from all treatments, but no statistical differences were observed.

EXPT. 2. Number OF APPLICATIONS. No growth differences were observed between the three application timing treatments [ $($ mean \pm $\mathrm{SE}$ ) Untreated $=92.9 \pm 6.2 \mathrm{~cm}$, Early $=79.0 \pm 6.7 \mathrm{~cm}$, and Late $=81.8 \pm$ $\left.5.6 \mathrm{~cm} ; \chi^{2}{ }_{(2)}=2.96, P=0.23\right]$. Untreated trees had more spider mites than both of the swirski mite treatments (Table 2). Untreated and Two treatments had lower Other Insect counts than the Three treatment. Total numbers of prey were lowest in the Two sachet application treatment and pest populations remained low for the 6-week sampling period when compared with the Untreated and Three treatments (Fig. 2). Interestingly, the total number of predatory mites recovered over 6 weeks was greatest on the Untreated controls (Table 2).

Expt. 3. Full sun vs. Shade. Flowering dogwood plants grew more under Shade than under Sun conditions $[($ mean \pm SE $)$ Shade $=62.4 \pm$ $3.8 \mathrm{~cm}$ and $\operatorname{Sun}=37.0 \pm 3.3 \mathrm{~cm}$; $\left.\chi_{(1)}^{2}=17.68, P<0.001\right]$. Total pest count was lower on Shade plants than on plants grown in Sun (Table 3). Broad mite egg and thrips totals were higher in Sun than in Shade, but no difference was observed in the number of adult broad mite in both treatments. Predatory mites were recovered from both treatments, but numbers were too low for analysis. From the 29 June 2016 sampling date on, consistent suppression of target plant pests was achieved by swirskii, although thrips continued to appear in the Sun treatment and broad mite persisted at low levels under Shade (Fig. 3).

\section{Discussion}

The presence of swirski mite sachets on containerized red maples suppressed target pest outbreaks in the first two experiments. Although swirski mite is sold commercially as a major predator of thrips and whitefly, its wide host range allows it to provide management of other pests of maple, including broad and spider mite. This flexibility allowed the sachet treatment to provide protection against broad mite in small, fast growing trees and spider mite, in larger, slower growing trees (Fig. 1). Both of these pests can create the need for miticide treatments in containerized maples. Broad mite is particularly difficult to control with miticides, given their preference for new foliage that has not fully expanded. It can be difficult for miticide sprays to contact broad mite sheltering within the newly expanding foliage, creating a need for multiple applications of miticides to successfully control broad mite. Predatory mites are mobile and, therefore, can forage for broad mites in the shelter of the newly emerging leaves where contact miticide sprays may not reach. Although spider mites are not preferred hosts of swirski mite, the plant size trials

Table 1. Arthropod total counts on nos. 3 and 15 container-grown 'Sun Valley' red maple trees treated with swirski mite controlled-release sachets or untreated controls.

\begin{tabular}{|c|c|c|c|c|c|c|c|}
\hline Treatment $^{\mathrm{z}}$ & Thrips (no.) & $\begin{array}{c}\text { Broad mite } \\
(\text { no. })\end{array}$ & $\begin{array}{c}\text { Broad mite } \\
\text { eggs (no.) }\end{array}$ & $\begin{array}{c}\text { Spider } \\
\text { mites (no.) }\end{array}$ & $\begin{array}{c}\text { Other } \\
\text { insects (no.) }\end{array}$ & $\begin{array}{c}\text { Total prey } \\
\text { (no.) }\end{array}$ & $\begin{array}{c}\text { Predatory } \\
\text { mites (no.) }\end{array}$ \\
\hline \multicolumn{8}{|l|}{ No. 3 containers } \\
\hline Swirski & 10 & $8 \mathrm{~b}$ & 1 & 0 & $12 \mathrm{a}$ & $31 \mathrm{~b}$ & 1 \\
\hline \multicolumn{8}{|l|}{ No. 15 containers } \\
\hline Untreated & 9 & $20 \mathrm{a}$ & $6 \mathrm{~b}$ & $153 \mathrm{a}$ & $560 \mathrm{a}$ & 748 a & 23 \\
\hline Treatment $(\mathrm{T})$ & 0.12 & 0.06 & 0.16 & 0.03 & 0.38 & 0.02 & 0.34 \\
\hline Container (C) & 0.07 & 0.79 & $<0.001$ & $<0.001$ & $<0.001$ & $<0.001$ & $<0.001$ \\
\hline $\mathrm{T} \times \mathrm{C}$ & 0.74 & 0.17 & 0.16 & 0.12 & 0.27 & 0.94 & 0.13 \\
\hline
\end{tabular}

${ }^{\mathrm{z}}$ Nos. 3 and $15=3$ and $13.4 \mathrm{gal}(11.4$ and $50.72 \mathrm{~L})$ container sizes of trees; Untreated $=$ no swirski mite controlled-release sachets; Swirski $=$ treated with swirski mite sachets. ${ }^{y}$ Arthropod totals in columns followed by lowercase letters are significantly different using Fisher's protected least significant difference at $P \leq 0.05$. Values with no lowercase letters were too low for statistical analysis.

${ }^{x}$ Probability values for generalized linear model $\chi^{2}$ analysis. Absent probability values appear where the model failed to converge because of low count numbers 

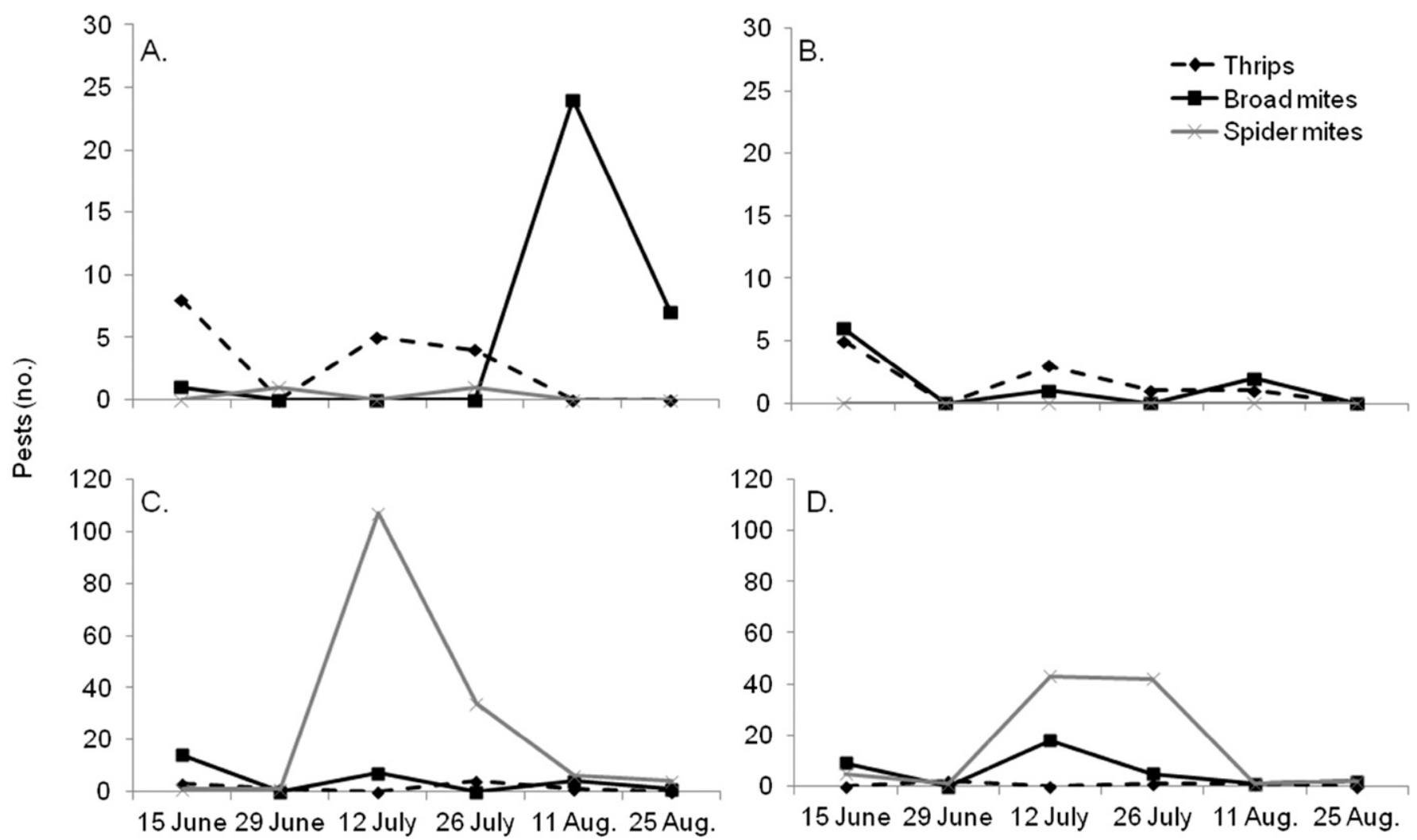

Sampling date

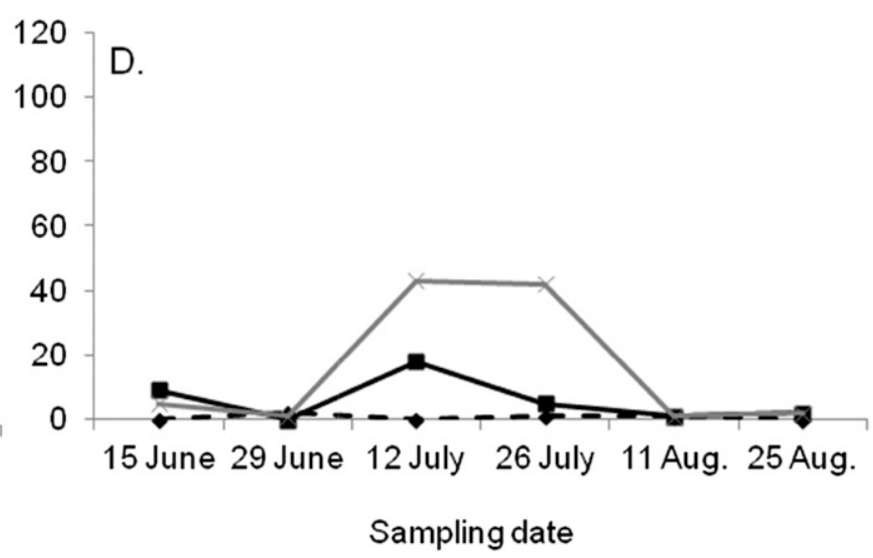

Fig. 1. Biweekly total pest counts on 'Sun Valley' red maple trees in (A) untreated no. 3 [3 gal (11.4 L)] containers (B) swirski mite controlled-release sachet-treated no. 3 containers, $(C)$ untreated no. 15 [13.4 gal (50.72 L)] containers, and (D) swirski mite-treated no. 15 containers.

Table 2. Arthropod total counts on no. 3 container-grown 'Franksred' Red Sunset ${ }^{\circledR}$ red maple trees treated with swirski mite controlled-release sachets applied at transplant (Three), on movement to the container yard (Two), and Untreated controls. ${ }^{\mathrm{z}}$

\begin{tabular}{|c|c|c|c|c|c|c|c|}
\hline Treatment $^{\mathrm{y}}$ & $\begin{array}{c}\text { Thrips } \\
\text { (no.) }\end{array}$ & $\begin{array}{c}\text { Broad } \\
\text { mites (no.) }\end{array}$ & $\begin{array}{c}\text { Broad } \\
\text { mite eggs (no.) }\end{array}$ & $\begin{array}{c}\text { Spider } \\
\text { mites (no.) }\end{array}$ & $\begin{array}{c}\text { Other } \\
\text { insects (no.) }\end{array}$ & $\begin{array}{c}\text { Total prey } \\
\text { (no.) }\end{array}$ & $\begin{array}{l}\text { Predatory } \\
\text { mites (no.) }\end{array}$ \\
\hline Untreated & $15^{x}$ & $4 \mathrm{a}$ & 6 & $13 a$ & 23 & $61 \mathrm{a}$ & $16 \mathrm{a}$ \\
\hline Three & 15 & $3 a$ & 0 & $3 \mathrm{~b}$ & 58 & $79 \mathrm{a}$ & $1 \mathrm{~b}$ \\
\hline Two & 11 & $0 \mathrm{~b}$ & 1 & $1 \mathrm{~b}$ & 14 & $23 \mathrm{~b}$ & $0 \mathrm{~b}$ \\
\hline \multicolumn{8}{|c|}{ Significance $(P \text { value })^{\mathrm{w}}$} \\
\hline Treatment & 0.79 & 0.01 & $一^{\mathrm{v}}$ & 0.01 & 0.36 & 0.11 & $<0.001$ \\
\hline
\end{tabular}

${ }^{\mathrm{z}}$ No. $3=3$ gal $(11.4 \mathrm{~L})$ container size of trees.

${ }^{y}$ Untreated = no swirski mite sachets; Three = sachets applied on 31 Mar. (at transplant), 29 Apr., and 22 June 2016 ; Two = sachets applied on 29 Apr. and 22 June 2016. ${ }^{x}$ Arthropod totals in columns followed by lowercase letters are significantly different using Fisher's protected least significant difference at $P \leq 0.05$. Values with no lowercase letters were too low for statistical analysis.

"Probability values for generalized linear model $\chi^{2}$ analysis. Absent probability values appear where the model failed to converge because of low count numbers.

${ }^{\mathrm{v}}$ Counts too low for statistical analysis.

present evidence that treatment with this predator can suppress spider mite outbreaks in large trees.

The addition of an additional, early sachet application did not improve pest control on plants in the no. 3 containers. This is likely due to the early season plants not having enough of a pest population to sustain the predatory mites, resulting in them cannibalizing one another and/or dispersing from the empty host patch.
Surprisingly, we recovered the most predatory mites in the Untreated plants. The spike in predator recovery occurred on 12 and 26 July, 3 and 5 weeks after the 22 June predator sachets were deployed. The plants in this experiment were kept in the same container yard with only 2 -m spacing between the treatments for the purpose of maintaining a similar production climate. Swirski mite is not known to disperse far on their own, particularly when plant canopies are discontinuous. Buitenhuis et al. (2010) documented a mean dispersal on potted 'Chesapeake' chrysanthemum (Dendranthema grandiflora) of $8 \mathrm{~cm}$ in $14 \mathrm{~d}$, with most mites found within $30 \mathrm{~cm}$ of the release site and a few up to $60 \mathrm{~cm}$ away. Given the short dispersal distances, we suspect that predator populations appearing on the Untreated plants were most likely dispersed by wind (Jung and 
Croft, 2001). We cannot discount the additional possibilities of phoretic movement by the mites on other mobile insects or natural predator populations entering the container yard. Mites in the family Phytoseiidae are difficult to identify to species, even with molecular tools. Identity of recovered predatory mites was, therefore, made at the family level.

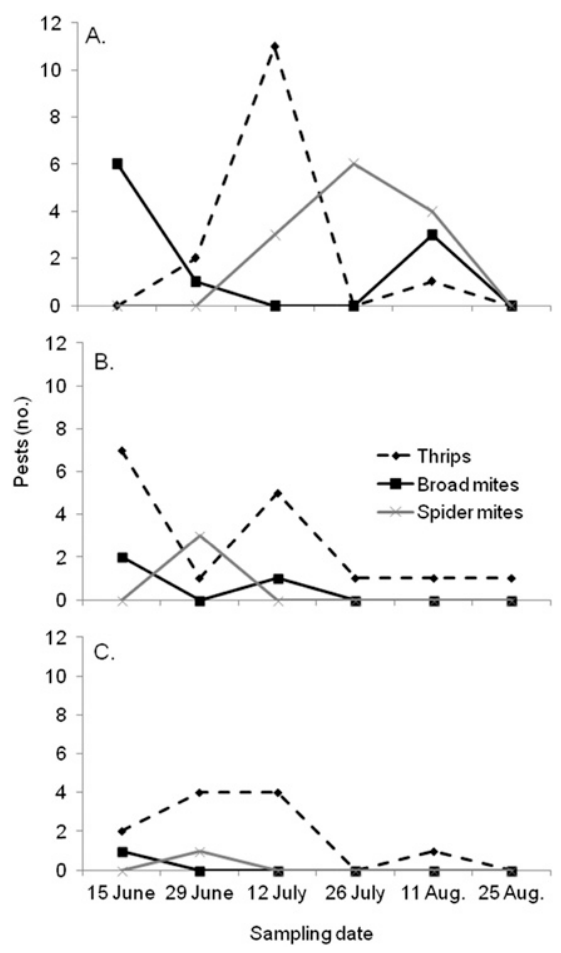

Fig. 2. Biweekly total pest counts on no. 3 [3 gal (11.4 L)] containergrown 'Franksred' Red Sunset ${ }^{\circledR}$ red maple trees in (A) untreated controls (Untreated), (B) rooted cuttings with first swirski mite controlled-release sachet treatment applied at transplant (Three), and (C) treatment on movement to the container yard (Two) 1 month later.
However, we predict that smaller trees may be less suitable to predators because of the likelihood that predator populations will outstrip prey resources. Once all prey items have been consumed, the predators must disperse or cannibalize each other, leaving the plant, once again, vulnerable to reinvading pest species. The later application of predators at the end of April was sufficient to suppress pest outbreaks at a lower cost of materials and labor (two vs. three applications).

Previous work by Burrows et al. (2015) demonstrated that dogwoods grown under $50 \%$ white shade grew more than plants in full sun under otherwise similar conditions. The positive growth effect of shade was supported by our results. More newly expanding foliage provides greater opportunity for broad mite infestations. The authors have observed that broad mite outbreaks at the Tennessee State University Otis L. Floyd Nursery Research Center have occurred earlier and with greater severity in shade houses and in container pads in full sun. With little knowledge of how swirski mite would perform under variable microclimates, we evaluated that the sachet treatments under full sun and $50 \%$ shade to see if the predators performed differently under the two growing conditions. Overall, predators appeared to perform better under shade, with fewer thrips, broad mite eggs, and total prey recovered in the shade treatment. However, more detailed study of microclimate may be necessary because of the lack of untreated controls in this trial. Future studies should evaluate microclimate parameters at predator release sites as these are known to affect predator survival (Buitenhuis et al., 2014; Shimoda et al., 2017) and dispersal ability of pests in and out of the shade houses.

Environmental conditions such as heat and moisture can affect the success of the sachets. Sachets applied to containerized plants in outdoor production may come into contact with pesticides or water through overhead irrigation systems or rain events. Shimoda et al. (2017) found that the number of predators in unsheltered sachets was drastically decreased after spraying with a nonselective pesticide or water, simulating rain, or overhead irrigation. To address these concerns, they developed a waterproof shelter for the sachets to decrease their exposure. The sheltered sachets had more predators following spray applications and those predator colonies continued to disperse.

When new, the sachets come complete with a cardboard hanger, which makes them easy to attach to a branch within the tree canopy. However, rain and irrigation can quickly deteriorate the sachet hangers, causing some of them to fall off the plants and into the container or onto the gravel yard. In cases where the sachet hangers failed in our experiments, they were quickly reattached, but doing so was inconvenient, and depending on how long the sachet was in the field, contact with the ground may have diminished the integrity of the predator colony. In addition to rain and nontarget pesticide effects, temperature and humidity are concerns for optimal predator colony development. A greenhouse trial of sachets containing cucumeris mite (Neoseiulus cucumeris) confirmed that shaded canopy placement is critical (Buitenhuis

Table 3. Arthropod total counts on no. 5 container-grown 'Cherokee Princess' flowering dogwood trees grown in $50 \%$ shade or full sun and treated with swirski mite controlled-release sachets. ${ }^{\mathrm{z}}$

\begin{tabular}{|c|c|c|c|c|c|c|c|}
\hline Treatment $^{\mathrm{y}}$ & $\begin{array}{l}\text { Thrips } \\
\text { (no.) }\end{array}$ & $\begin{array}{c}\text { Broad } \\
\text { mites } \\
(\text { no. })\end{array}$ & $\begin{array}{l}\text { Broad mite } \\
\text { eggs (no.) }\end{array}$ & $\begin{array}{c}\text { Spider mites } \\
\text { (no.) }\end{array}$ & $\begin{array}{c}\text { Other insects } \\
\text { (no.) }\end{array}$ & $\begin{array}{l}\text { Total prey } \\
\text { (no.) }\end{array}$ & $\begin{array}{c}\text { Predatory mites } \\
\text { (no.) }\end{array}$ \\
\hline Shade & $1 b^{x}$ & 19 & $2 \mathrm{~b}$ & 3 & 2 & $27 \mathrm{~b}$ & 3 \\
\hline \multicolumn{8}{|c|}{ Significance $(P \text { value })^{\mathrm{w}}$} \\
\hline Treat & 0.001 & 0.78 & 0.07 & $一^{\mathrm{v}}$ & - & 0.14 & - \\
\hline
\end{tabular}

${ }^{\mathrm{z}}$ No. $5=3.7 \mathrm{gal}(14.01 \mathrm{~L})$ container size of trees.

${ }^{\mathrm{y}} \mathrm{Shade}=$ plants grown under $50 \%$ white shadecloth; Sun $=$ plants grown in full sun

${ }^{x}$ Arthropod totals in columns followed by lowercase letters are significantly different using Fisher's protected least significant difference at $P \leq 0.05$. Values with no lowercase letters were too low for statistical analysis.

${ }^{\text {w }}$ Probability values for generalized linear model $\chi^{2}$ analysis. Absent probability values appear where the model failed to converge because of low count numbers.

${ }^{v}$ Counts too low for statistical analysis. 


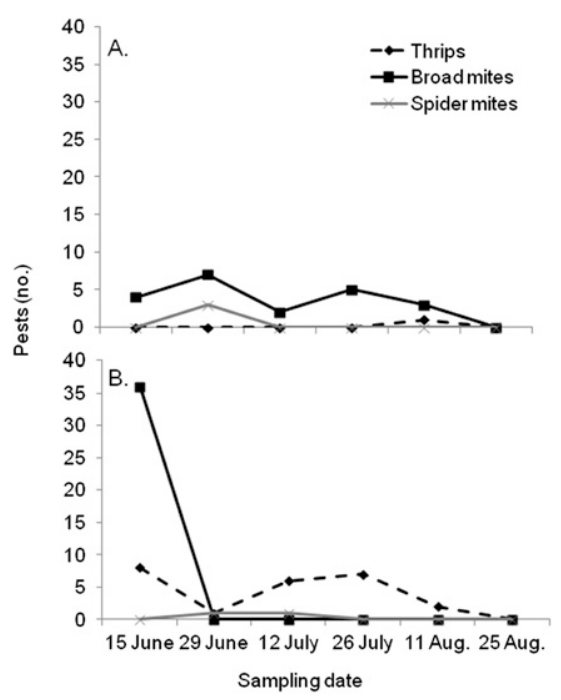

Fig. 3. Biweekly total pest counts on no. 5 [3.7 gal (14.01 L)] containergrown 'Cherokee Princess' flowering dogwood trees treated with controlled-release sachets and grown in (A) $50 \%$ white shade and (B) full sun.

et al., 2014). Exposed sachets had higher mean and maximal internal temperatures and the predators dispersed quickly, with no reproduction observed within the sachets. While our sachets were tucked inside the branches of each plant, no additional effort was made to create shelters for the sachets. In future work, newer waterproof sachets will be used in production trials where overhead irrigation, rain, or both are expected to be a problem.

Our main reason for evaluating sachets for outdoor nursery production is the problem of predator dispersal. Predatory mites disperse most readily in continuous canopies, which is not always characteristic of container and field nursery production. In row crops and greenhouses, dispersal of predators is often aided by closed canopies or the placement of interplant bridges. Casey and Parrella (2005) observed that persimilis mite was more evenly dispersed across a greenhouse when mites were dispersed by plastic flagging tape used as interplant bridges. An additional method of predator dispersal is through application of mites with a mechanical blower. Casey and Parrella (2005) found this method, like the interplant bridges, to decrease twospotted spider mite infestations by $50 \%$ compared with controls with no dispersal aid. In addition to aiding in dispersal, an equally important aspect of blower application is time saving. Opit et al. (2005) evaluated a metered blower device and found that it applied predatory mites 44 times faster than manual sprinkling applications. The challenge with blower applications in container and field production is that predators are also applied to open spaces between plants, resulting in both economic and control losses. Predators landing on gravel or soil have to contend with harsh environmental conditions and predators may never make it to their intended application sites.

Our results suggest that swirski mite may be a good candidate for use in outdoor woody ornamental production as a generalist predatory of key mite and insect pests in the southeastern United States. One of the major obstacles for adoption of biological control methods is a lack of threshold data for treatment of damage by various mite and insect herbivores in woody ornamental production. In general, thresholds for aesthetic damage are at or near zero for plants that will be sold within the current season. Damage that negatively affects the growth of new foliage, such as broad mite, eriophyid mite, and thrips damage will also have a much lower threshold for treatment throughout the production cycle. In addition, comparative studies with conventional pesticide applications should be evaluated to assess the degree to which biological control methods meet or exceed pesticide management standards. More work in this area is needed to address efficacy, optimal application methods, and cost-effectiveness of biological control applications to high-value woody crops and/or for pest problems that are difficult to manage with conventional pesticides.

\section{Literature cited}

Buitenhuis, R., E. Glemser, and A. Brommit. 2014. Practical placement improves the performance of slow release sachets of Neoseiulus cucumeris. Biocontrol Sci. Technol. 24:11531166.

Buitenhuis, R., G. Murphy, L. Shipp, and C. Scott-Dupree. 2015. Amblyseius swirskii in greenhouse production systems: A floricultural perspective. Expt. Appl. Acarol. 65:451-464.
Buitenhuis, R., L. Shipp, and C. ScottDupree. 2010. Dispersal of Amblyseius swirskii Athias-Henriot (Acari: Phytoseiidae) on potted greenhouse chrysanthemum. Biol. Control 52:110-114.

Burrows, M.W., D.C. Fare, C.H. Gilliam, and D.J. Eakes. 2015. Influence of shading on container-grown flowering dogwoods. Proc. Southern Nursery Assn. Resources Conf. 60:11-18.

Calvo, F.J., M. Knapp, Y.M. van Houten, H. Hoogerbrugge, and J.E. Belda. 2015. Amblyseius swirskii: What made this predatory mite such a successful biocontrol agent? Expt. Appl. Acarol. 65:419-433.

Casey, C., J. Newman, K. Robb, S. Tjosvold, J. MacDonald, and M.P. Parella. 2007. IPM program successful in California greenhouse cut roses. Calif. Agr. 61(2):71-78.

Casey, C.A. and M.P. Parrella. 2005. Evaluation of a mechanical dispenser and interplant bridges on the dispersal and efficacy of the predator, Phytoseiulus persimilis (Acari: Phytoseiidae) in greenhouse cut roses. Biol. Control 32:130-136.

Cashion, G.J., H. Bixler, and J.F. Price. 1994. Nursery IPM trials using predatory mites. Proc. Florida State Hort. Soc. 107:220-222.

Delisle, J.F., J. Brodeur, and L. Shipp. 2015. Evaluation of various types of supplemental food for two species of predatory mites, Amblyseius swirskii and Neoseiulus cucumeris (Acari: Phytoseiidae). Expt. Appl. Acarol. 65:483-494.

Goleva, I. and C.P.W. Zebitz. 2013. Suitability of different pollen as alternative food for the predatory mite Amblyseius swirskii (Acari: Phytoseiidae). Expt. Appl. Acarol. 61:259-283.

Hewitt, L.C., L. Shipp, R. Buitenhuis, and C. Scott-Dupree. 2015. Seasonal climatic variations influence the efficacy of predatory mites used for control of western flower thrips in greenhouse ornamental crops. Expt. Appl. Acarol. $65: 435-450$.

Hoogerbrugge, H., Y. van Houten, E. van Baal, and K. Bolckmans. 2008. Alternative food sources to enable establishment of Amblyseius swirskii (AthiasHenriot) on chrysanthemum without pest presence. Intl. Organisation Biol. Integrated Control, West Palaearctic Reg. Section Bul. 32:79-82.

Juan-Blasco, M., J.A. Qureshi, A. Urbaneja, and P. Stansly. 2012. Predatory mite, Amblyseius swirskii (Acari: Phytoseiidae), for biological control of asian citrus psyllid, Diaphorina citri (Hemiptera: Psyllidae). Fla. Entomol. 95:543551 . 
Jung, C. and B.A. Croft. 2001. Aerial dispersal of phytoseiid mites (Acari: Phytoseiidae): Estimating falling speed and dispersal distance of adult females. Oikos 94:182-190.

Lee, H. and D.R. Gillespie. 2011. Life tables and development of Amblyseius swirskii (Acari: Phytoseiidae) at different temperatures. Expt. Appl. Acarol. 53:1727.

North Carolina State University. 2017. Southeastern US pest control guide for nursery crops and landscape plantings. 1 Jan. 2018. <https://content.ces.ncsu. edu/southeastern-us-pest-control-guidefor-nursery-crops-and-landscapeplantings $>$.

Onzo, A., A.F. Houedokoho, and R. Hanna. 2012. Potential of the predatory mite, Amblyseius swirskii to suppress the broad mite, Polyphagotarsonemus latus on the gboma eggplant, Solanum macrocarpon. J. Insect Sci. 12:7 (abstr.).

Opit, G.P., J.R. Nechols, D.C. Margolies, and K.A. Williams. 2005. Survival, horizontal distribution, and economics of releasing predatory mites (Acari: Phytoseiidae) using mechanical blowers. Biol. Control 33:344-351.

Palevsky, E., Y. Argov, T. Ben-David, and U. Gerson. 2003. Identification and evaluation of potential predators of the citrus rust mite, Phyllocoptruta oleivora, in Israel. Syst. Appl. Acarol. 8:1-10.
Peña, J.E. and L. Osborne. 1996. Biological control of Polyphagotarsonemus latus (Acarina: Tarsonemidae) in greenhouses and field trials using introductions of predacious mites (Acarina: Phytoseiidae). BioControl 41:279-285.

Pilkington, L.J., G. Messelink, J.C. van Lenteren, and K. Le Mottee. 2010. Protected biological control-Biological pest management in the greenhouse industry. Biol. Control 52:216-220.

Pratt, P.D. and B.A. Croft. 2000. Screening of predatory mites as potential control agents of pest mites in landscape plant nurseries of the Pacific Northwest. J. Environ. Hort. 18:218-223.

Pratt, P.D., R. Rosetta, and B.A. Croft. 2002. Plant-related factors influence the effectiveness of Neoseiulus fallacis (Acari: Phytoseiidae), a biological control agent of spider mites on landscape ornamental plants. J. Econ. Entomol. 95:1135-1141.

Shimoda, T., Y. Kagawa, K. Mori, N. Hinomoto, T. Hiraoka, and T. Nakajima. 2017. A novel method for protecting slow-release sachets of predatory mites against environmental stresses and increasing predator release to crops. BioControl 62:495-503.

Southern IPM Center. 2018. National IPM database. 7 Mar. 2018. <https:// ipmdata.ipmcenters.org $>$.
Southern Nursery IPM Working Group. 2014. IPM priorities: Key pests, plant diseases and weeds for container and fieldproduced nursery crops in the southeast U.S. 1 Jan. 2018. <http://www.sripmc.org/ Policy/Priorities/SNIPM_Priorities.pdf $>$.

Tal, C., M. Coll, and P.G. Weintraub. 2007. Biological control of Polyphagotarsonemus latus by the predaceous mite Amblyseius swirskii, p. 111-115. In: P.G. Weintraub (ed.). Integrated control of plant-feeding mites. Intl. Organization Biol. Integrated Control, West Palaearctic Reg. Section Bul. 30.

van Driesche, R.G. and S. Lyon. 2003. Commercial adoption of biological control-based IPM for whiteflies in poinsettia. Fla. Entomol. 86:481-483.

van Maanen, R., E. Vila, M.W. Sabelis, and A. Janssen. 2010. Biological control of broad mites (Polyphagotarsonemus latus) with the generalist predator Amblyseius swirskii. Expt. Appl. Acarol. 52:29-34.

Xiao, Y., P. Avery, J. Chen, C. McKenzie, and L. Osborne. 2012. Ornamental pepper as banker plants for establishment of Amblyseius swirskii (Acari: Phytoseiidae) for biological control of multiple pests in greenhouse vegetable production. Biol. Control 63:279-286. 